\title{
Evaluasi Program Community-Based Learning yang Berdampak pada Perilaku Kerjasama Siswa SMP X Depok
}

\author{
Tina Sugiharti ${ }^{1}$, Riana Sahrani ${ }^{2}$, Raja Oloan Tumanggor $^{3}$ \\ ${ }^{1}$ Fakultas Psikologi, Universitas Tarumanagara Jakarta \\ Email: tinasugiharti80@gmail.com \\ ${ }^{2}$ Fakultas Psikologi, Universitas Tarumanagara Jakarta \\ Email: rianas@fpsi.untar.ac.id \\ ${ }^{3}$ Fakultas Psikologi, Universitas Tarumanagara Jakarta \\ Email: rajat@fpsi.untar.ac.id
}

\begin{abstract}
ABSTRAK
Program Community-Based Learning (CBL) merupakan salah satu kegiatan yang dilaksanakan di SMP X Depok untuk memfasilitasi siswa dalam mengaplikasikan model Pendidikan Holistik Berbasis Karakter (PHBK) di masyarakat. Kerjasama merupakan salah satu aspek karakter yang diaplikasikan dalam CBL. Perilaku kerjasama tersebut belum muncul secara konsisten pada seluruh siswa yang telah melaksanakan CBL. Oleh karena itu dilakukan penelitian evaluasi terhadap program CBL ini. Penelitian bertujuan mengevaluasi dampak program CBL pada perilaku kerjasama siswa. Partisipan adalah siswa kelas 9 yang mengikuti CBL pada tahun 2015. Empat dari 20 partisipan diperoleh secara purposive sampling berdasarkan skor tertinggi kuesioner perilaku kerjasama (Tarricone \& Luca, 2002). Model evaluasi yang digunakan adalah reciprocal determinism (teori sosial kognitif) terhadap pelaksanaan CBL. Penelitian ini menggunakan teknik pengumpulan data observasi dan wawancara. Teknik observasi dilakukan menggunakan daftar check list yang meliputi faktor kognitif, behavior dan environment pada setting kerja kelompok di kelas, focus group discussion (FGD), dan simulasi. Teknik wawancara menggunakan pedoman wawancara berdasarkan teori CBL terhadap terhadap 4 partisipan, serta kepala sekolah dan guru sebagai pendukung triangulasi data. Hasil penelitian menunjukkan bahwa program CBL memberikan dampak terhadap peningkatan perilaku kerjasama para siswa. Peningkatan itu terjadi pada aspek semangat, kekompakan, saling menghargai, dan usaha untuk total saat mengerjakan tugas kelompok. Sementara aspek lain yaitu pelaksanaan peran dalam kelompok, sudah ada ada namun tidak meningkat karena ketidakkonsistenan dari perilaku kerjasamanya.
\end{abstract}

Kata kunci: evaluasi program, community-based learning, karakter, kerjasama, Sekolah Menengah Pertama

\section{PENDAHULUAN}

Sekolah Menengah Pertama (SMP) X Depok adalah sekolah swasta yang memiliki Visi: "Membangun Bangsa Berkarakter, Cerdas dan Kreatif", yang menerapkan model Pendidikan Holistik Berbasis Karakter (PHBK) dalam kegiatan pembelajarannya. Salah satu aspek yang ingin dicapai dari para siswa pada awal berdirinya SMP X di Depok adalah, bagaimana para siswa dapat siap untuk terjun ke masyarakat setelah lulus dari SMP X sebagai wujud dari tercapainya salah satu Misi Sekolah di SMP X yaitu "Berkarakter baik dan bermanfaat bagi lingkungan". Diantara banyak kegiatan yang dilakukan untuk mewujudkan misi sekolah dalam hal karakter, terdapat sebuah program yang dilaksanakan di SMP X yaitu Community-BasedLearning $(C B L)$.

Program $C B L$ yang diterapkan di SMP X merupakan kegiatan rutin yang telah ditetapkan di dalam kalender akademik sekolah di awal tahun ajaran. Stakeholder dari program ini terdiri dari: kepala sekolah, para guru, siswa kelas 8, orang tua siswa, pengelola TK/Semai Benih Bangsa (SBB) di lokasi $C B L$ yang merupakan mitra SMP X dan telah menerapkan PHBK, pengelola SD di lokasi $C B L$, Unit Pelaksana Teknis Daerah (UPTD) di lokasi $C B L$, dan pemilik rumah tinggal selama melaksanakan program $C B L$. Program $C B L$ di SMP X telah dilaksanakan sejak tahun 2011 hingga sekarang dan dilakukan oleh siswa kelas 8. Kegiatan $C B L$ yang dilaksanakan di SMP X terdiri dari 3 tahap, yaitu: persiapan, pelaksanaan, dan pelaporan. 
Program $C B L$ memiliki manfaat dalam beberapa aspek, yaitu aspek karakter; aspek pembelajar sejati; aspek kreatif dan terbuka; dan aspek keterampilan hidup. Contoh perilaku konkrit manfaat dalam aspek karakter adalah: kesabaran, mandiri, disiplin, tanggung jawab, kerjasama, percaya diri, dan empati. Siswa SMP X yang mengikuti $C B L$ pada tanggal $14-19$ September 2015, saat ini duduk di kelas 9. Dengan kata lain, telah satu tahun sejak para siswa ini mengikuti kegiatan $C B L$. Berdasarkan hasil penelusuran melalui komunikasi pribadi dengan tiga guru yang menjadi panita $C B L$ tahun 2015, diperoleh hasil pengamatan terkait karakter. Saat ini dari 20 siswa, belum seluruh siswa yang pernah mengikuti $C B L$ menunjukkan perkembangan yang konsisten dalam karakter amanah, tanggung jawab, kepemimpinan, dan bagaimana menjalin kerjasama dalam sebuah tim.

$C B L$ adalah strategi pembelajaran yang memungkinkan remaja dan orang dewasa mempelajari apa yang ingin mereka pelajari dari setiap segmen masyarakat (Owens \& Wang, 1996). Menurut Melaville, Berg, dan Blank (2006), CBL memiliki manfaat untuk membantu siswa membangun rasa koneksi mereka dengan masyarakat. Adapun menurut Roehlkepartain (2007) salah satu manfaat dari kegiatan community based-service learning adalah dapat meningkatkan kemampuan bekerja dalam tim. Sementara itu berdasarkan 62 studi meta-analysis yang melibatkan 11.837 siswa di Amerika Serikat, menunjukkan hasil bahwa siswa yang berpartisipasi dalam program service learning memiliki hasil yang signifikan dalam lima area, yaitu sikap terhadap diri, sikap terhadap sekolah dan belajar, keterlibatan dengan masyarakat, kemampuan sosial, dan performa akademik (Celio, Durlak, \& Dymnicki, 2011). CBL juga erat kaitannya dengan peran pemuda sebagai sumberdaya yang dapat dilibatkan dalam pengembangan masyarakat. Menurut Brennan dan Barnett (2009), kontribusi remaja dalam pengembangan masyarakat memiliki manfaat bagi remaja tersebut berupa peningkatan keterampilan, membangun kepercayaan diri, dan mengembangkan kepemimpinan melalui kolaborasi / kerjasama antara remaja dan orang dewasa di masyarakat.

Berdasarkan pemaparan dari keempat sumber mengenai kegiatan belajar berbasis masyarakat $(C B L)$ dapat disimpulkan, bahwa $C B L$ memberikan dampak positif terhadap beberapa perkembangan karakter, antara lain kerjasama (Roehlkepartain, 2007; Celio, Durlak, \& Dymnicki, 2011; Brennan \& Barnett, 2009). Hal ini sejalan dengan program $C B L$ yang dilaksanakan di SMP $X$, yang salah satu tujuannya yaitu memfasilitasi siswa dalam mengaplikasikan model Pendidikan Holistik Berbasis Karakter (PHBK) di luar sekolah, dalam hal ini lingkungan masyarakat yang lebih luas. Kerjasama adalah salah aspek karakter yang diajarkan di SMP X. Kerjasama adalah sekelompok orang dengan keterampilan yang saling melengkapi, yang berkomitmen untuk tujuan yang sama dan saling bertanggung jawab dalam mencapai tujuan tersebut (Constructing Excellence, 2004). Karakter kerjasama sangatlah penting untuk ditingkatkan dalam diri siswa SMP yang berusia remaja, dan salah satu contoh kegunaannya adalah ketika para remaja tersebut memasuki dunia kerja saat mereka dewasa. Kerjasama seringkali diimplementasikan dalam perusahaan karena menghasilkan manfaat penting, seperti adanya peningkatan dalam semangat kerja, spesialisasi tugas-tugas kerja, dan transfer pengetahuan dalam dunia kerja (Rullière, Santos-Pinto, \& Vialle, 2011).

Berdasarkan hasil penelusuran melalui komunikasi pribadi dengan tiga guru yang menjadi panitia $C B L$ di SMP X pada tahun 2015, diperoleh pengamatan terkait karakter. Saat ini dari 20 siswa, sebagian besar siswa sudah menunjukkan peningkatan dalam beberapa karakter yang diajarkan, yaitu mandiri, disiplin, jujur, amanah, hormat dan santun, dermawan, suka menolong, percaya diri, kreatif, pantang menyerah, baik dan rendah hati, toleransi, cinta damai, kesatuan, K4. Namun, saat ini belum seluruh siswa yang pernah mengikuti $C B L$ menunjukkan 
perkembangan yang konsisten dalam karakter amanah, tanggung jawab, kepemimpinan, dan bagaimana menjalin kerjasama dalam sebuah tim. Berdasarkan informasi guru tersebut, karakter kerjasama menjadi hal yang masih perlu ditingkatkan dalam diri siswa di SMP X setelah mereka mengikuti program $C B L$. Hal ini menjadi salah satu acuan penulis, bahwa terdapat perbedaan antara hasil pengamatan guru di SMP X dengan teori yang dikemukakan oleh Roehlkepartain (2007); Celio, Durlak, dan Dymnicki (2011); Brennan dan Barnett (2009), bahwa CBL memberikan dampak terhadap pengembangan karakter siswa antara lain karakter kerjasama. Oleh karena itu, perlu dilakukan kajian/penelitian evaluasi secara ilmiah mengenai program $C B L$ tentang sejauh mana kesesuaian program $C B L$ yang telah dilaksanakan di SMP X dengan prinsip dan pedoman program $C B L$, serta sejauh mana dampak dari program ini terhadap aspek karakter kerjasama siswa setelah mereka mengikuti program. Penelitian evaluasi (evaluation research) adalah, penelitian terapan yang dilakukan untuk menentukan seberapa baik sebuah program atau kebijakan bekerja atau sejauh mana program tersebut mencapai tujuan dan sasarannya (Newman, 2014).

Evaluation research memiliki beberapa model. Menurut Owston (2008), model evaluation research terdiri dari Decision-Making Evaluation Approaches, Naturalistic Evaluation Approaches, dan Kirkpatrick's Four Levels. Dari ketiga model evaluation research tersebut, Kirkpatrick's Four Levels merupakan model evaluasi yang sesuai untuk menggambarkan perilaku siswa dan sejalan dengan model reciprocal determinism dari Albert Bandura. Model reciprocal determinism terdiri dari tiga faktor utama, yaitu: perilaku (behavior), individu/kognitif (person/cognitive), dan lingkungan (environment) (Bandura, 1989). Model penelitian reciprocal determinism digunakan dalam penelitian ini karena dapat menggambarkan perubahan perilaku (behavior), serta faktor kognisi dan lingkungan yang muncul dalam program $C B L$.

\section{METODE PENELITIAN}

Partisipan dalam penelitian ini adalah siswa kelas 9 SMP X dan telah mengikuti program $C B L$ pada tahun 2015. Empat dari 20 partisipan diperoleh secara purposive sampling berdasarkan skor tertinggi kuesioner perilaku kerjasama (Tarricone \& Luca, 2002). Isi kuesioner terdiri dari 15 item pernyataan yang mewakili dimensi-dimensi dalam kriteria komponen karakteristik tim/ kelompok yang sukses, sehingga total skor maksimal adalah 15. Peneliti membagi kategori perilaku kerjasama dari skor yang diperoleh menjadi tiga, yaitu kategori "baik" jika skor yang diperoleh antara 11 - 15; kategori "sedang" jika skor yang diperoleh antara $6-10$; kategori "rendah" jika skor yang diperoleh antara $1-5$.

Penelitian dilakukan di SMP X Kota Depok. Kegiatan pengisian kuesioner oleh 20 calon partisipan dilaksanakan dalam waktu yang disesuaikan dengan kondisi di kelas. Kegiatan observasi terhadap 4 partisipan dilaksanakan di dalam kelas dalam seting belajar seperti biasa, serta di luar kelas dalam seting $F G D$ dan simulasi. Kegiatan wawancara terhadap 4 partisipan dilaksanakan di luar jam pelajaran inti. Kegiatan wawancara terhadap kepala sekolah dan guru dilaksanakan sesuai dengan kesepakatan antara peneliti sebagai pewawancara dan narasumber.

Perlengkapan/instrumen yang digunakan pada penelitian ini yaitu informed-consent, kuesioner siswa tentang perilaku kerjasama, daftar check list observasi guru tentang perilaku kerjasama siswa, panduan wawancara untuk kepala sekolah dan guru, panduan wawancara untuk siswa, buku catatan, alat tulis, alat perekam, komputer, dan printer. Panduan wawancara digunakan sebagai pedoman untuk memudahkan peneliti dalam mengajukan pertanyaan agar tetap sesuai dengan konteks dari topik penelitian. Contoh pertanyaan dalam panduan wawancara siswa 
adalah: (1) jelaskan keterlibatan kamu dalam program $C B L$ ini, dari persiapan, pelaksanaan sampai dengan setelah pelaksanaan; (2) siapa saja yang melaksanakan program $C B L$ ini? (3) menurutmu, apa saja manfaat yang kamu peroleh setelah mengikuti program $C B L$ ini? Sedangkan contoh pertanyaan dalam panduan wawancara kepala sekolah dan guru adalah: (1) menurut Bapak/Ibu, apakah program $C B L$ yang selama ini sudah dilaksanakan sudah sesuai dengan tujuan program itu sendiri? (2) bagaimana dampak yang muncul setelah siswa mengikuti program $C B L$ ? (3) menurut Bapak/Ibu, bagaimana perilaku kerjasama yang muncul saat ini dalam diri siswa, setelah mereka mengikuti program $C B L$ ?

Prosedur dalam penelitian ini terdiri dari persiapan penelitian dan pelaksanaan penelitian. Persiapan awal yang dilakukan oleh peneliti ialah mencari dan menentukan tema penelitian. Kemudian, peneliti membuat perumusan masalah. Tahap berikutnya ialah mencari dan menyusun landasan teori yang akan digunakan untuk menjadi dasar dalam melakukan analisis data yang di peroleh. Selanjutnya, menentukan karakteristik partisipan penelitian yang disesuaikan dengan teori yang ada dan lokasi dari penelitian yang akan dilaksanakan. Setelah itu, peneliti menyusun informed consent, kuesioner tentang perilaku kerjasama untuk calon partisipan, lembar check list observasi guru tentang perilaku kerjasama partisipan, dan pedoman wawancara yang bertujuan untuk memudahkan peneliti dalam melakukan proses pengambilan data dengan partisipan penelitian.

Adapun pelaksanaan penelitian meliputi proses perizinan kepada SMP X, pemberian kuesioner karakter kerjasma kepada 20 siswa kelas 9 dan menentukan 4 siswa dengan skor perilaku kerjasama tertinggi sebagai partisipan penelitian. Kemudian peneliti bersama salah satu guru di SMP X melakukan observasi mengenai perilaku kerjasama yang muncul pada 4 partisipan. Langkah berikutnya adalah melakukan pertemuan dengan partisipan untuk melakukan proses wawancara mengenai pengalaman dalam kegiatan $C B L$ dan mengenai perilaku kerjasama dalam diri partisipan. Peneliti juga melakukan proses wawancara dengan kepala sekolah dan 4 guru di SMP X untuk memperoleh gambaran pelaksanaan program $C B L$ di SMP X. Setelah proses wawancara dengan semua partisipan dan guru selesai, peneliti mulai melakukan analisis dan interpretasi data yang telah diperoleh.

\section{HASIL DAN PEMBAHASAN}

Pelaksanaan penelitian dimulai dari tahap penentuan partisipan yang dilaksanakan pada hari Senin tanggal 24 Oktober 2016. Pada tahap ini, sebanyak 20 siswa kelas 9 SMP X tahun ajaran 2016-2017 diminta untuk mengisi kuesioner tentang perilaku kerjasama yang muncul dalam diri mereka saat ini setelah satu tahun mereka mengikuti program $C B L$. Berdasarkan perolehan skor, dari 20 siswa diperoleh empat siswa dengan skor perilaku kerjasama tertinggi, dan keempatnya memiliki karakter kerjasama dengan kategori "baik" karena memiliki total skor antara $11-15$. Oleh karena itu, keempat partisipan memiliki potensi untuk bekerja sama dengan baik.

Partisipan terpilih dalam penelitian ini terdiri dari dua siswa laki-laki dan dua siswa perempuan. Ayah dan Ibu dari tiga partisipan, yaitu ARI, IR, dan RA memiliki status bekerja, baik itu di instansi maupun wiraswasta. Partisipan An, hanya ayah yang bekerja sedangkan ibunya adalah ibu rumah tangga. Secara umum, seluruh partisipan termasuk siswa yang aktif mengikuti kegiatan di sekolah. Mereka memiliki kemampuan berkomunikasi yang baik, sehingga dapat mengutarakan pendapat maupun informasi secara jelas kepada orang lain.

Observasi terhadap keempat partisipan dilaksanakan dalam tiga bentuk, yaitu: (1) observasi di dalam kelas saat partisipan sedang mengikuti kegiatan belajar mengajar dalam bentuk kerja 
kelompok dengan teman-temannya; (2) FGD yang hanya diikuti oleh partisipan; (3) simulasi kerjasama yang hanya diikuti oleh partisipan. Observasi di kelas (observasi ke-1 dan ke-4) dilakukan dengan tujuan untuk mengetahui perilaku kerjasama yang muncul dalam diri partisipan selama kegiatan kelompok berlangsung. Adapun bentuk observasi $F G D$ (observasi ke2 dan ke-5) serta simulasi (observasi ke-3) bertujuan untuk mengetahui pemahaman siswa tentang karakter kerjasama dan mengetahui perilaku kerjasama yang muncul pada partisipan.

Berdasarkan lima kali observasi yang telah dilakukan, keempat partisipan telah menunjukkan keterlibatannya dalam kegiatan kelompok. Meskipun dapat diamati bahwa siswa perempuan (IR dan RA) cenderung menunjukkan kerjasama yang lebih tinggi dibandingkan siswa laki-laki (ARI dan Ar), namun keempatnya telah sama-sama berkontribusi dalam menyelesaikan setiap tugas kelompok yang diberikan. Keempat partisipan juga menunjukkan perilaku saling menghargai dan saling memahami, serta menjalin komunikasi yang terbuka satu sama lain. Dengan kata lain, keempat partisipan sudah berusaha menjadi bagian dari tim yang sukses (Tarricone \& Luca, 2002).

Berdasarkan hasil wawancara siswa pada komponen person (kognitif), seluruh partisipan sudah mengetahui dan memahami makna dari kerjasama serta cara untuk menjadi anggota tim yang sukses. Makna kerjasama yang telah dipahami oleh partisipan selaras dengan definisi kerjasama menurut Constructing Excellence (2004), yaitu adanya sekelompok orang dengan keterampilan yang saling melengkapi, yang berkomitmen untuk tujuan yang sama dan saling bertanggung jawab dalam mencapai tujuan tersebut.

Berdasarkan hasil wawancara siswa pada komponen behavior, seluruh partisipan sudah terlibat dalam kerjasama selama mengikuti program $C B L$. Selain itu seluruh partisipan menilai bahwa hingga saat ini mereka sudah konsisten menjadi bagian dari tim yang sukses setelah mengikuti program $C B L$ satu tahun yang lalu. Gambaran aspek behaviour partisipan saat mengikuti maupun setelah mengkuti kegiatan $C B L$ menunjukkan, adanya interaksi antara faktor kognisi mengenai makna kerjasama yang memberikan arahan perilaku untuk bekerjasama dengan baik (Bandura, 1989). Hasil wawancara siswa pada faktor behavior juga menunjukkan terdapat aspek kerjasama dalam hal pelaksanaan peran dalam kelompok, terutama peran ketua kelompok yang perlu ditingkatkan.

Adapun hasil wawancara siswa pada komponen environment menunjukkan bahwa, program $C B L$ di SMP X dapat terlaksana atas peran siswa, guru, orang tua, induk semang pemilik rumah tempat tinggal siswa, guru PAUD/TK tempat siswa melakukan magang. Peran siswa di masyarakat selama mengikuti program $C B L$ juga telah memberikan dampak positif bagi lingkungan/masyarakat di sekitar lokasi program. Dengan kata lain, terdapat hubungan sebab akibat antara faktor behaviour (perilaku) siswa dengan faktor environment (lingkungan) yaitu perilaku siswa di masyarakat telah mengubah kondisi lingkungan di sekitarnya (Bandura, 1989).

Wawancara dengan guru dan kepala sekolah bertujuan untuk mengetahui pelaksanaan program $C B L$ dan kaitannya dengan perilaku kerjasama pada siswa. Pelaksanaan program $C B L$ yang digali dari kepala sekolah dan guru didasarkan pada prinsip-prinsip $C B L$ (Melaville et al., 2006) dan pedoman pelaksanaan $C B L$ (Nova Scotia Department of Education and Early Childhood Development, 2013). Wawancara ini juga bertujuan untuk mengetahui dampak pelaksanaan $C B L$ menggunakan komponen hubungan timbal balik antara faktor person (kognitif), behavior dan environment (Bandura, 1989). Hasil wawancara dengan guru dan kepala sekolah menunjukkan 
bahwa, secara umum program $C B L$ di SMP X sudah memenuhi seluruh prinsip yang harus ada dalam program $C B L$ dan sudah memenuhi pedoman $C B L$.

Adapun hasil wawancara dengan guru dan kepala sekolah ditinjau dari komponen evaluasi program (faktor person, behavior dan environment) menunjukkan hasil sebagai berikut. Program $C B L$ yang dilaksanakan di SMP $\mathrm{X}$ telah memberikan dampak yang positif bagi siswa sebagai pelaksana maupun bagi lingkungan sekitarnya. Siswa memperoleh banyak pengetahuan yang bermanfaat setelah berbaur di masyarakat. Selain itu, para siswa memperoleh peningkatan pemahaman dalam keterampilan dan nilai-nilai kehidupan yang semuanya berasal dari hasil interaksi di masyarakat. Menurut penilaian guru dan kepala sekolah, para siswa juga menunjukkan peningkatan dalam hal karakter termasuk karakter kerjasama. Masyarakat juga memperoleh manfaat yang positif dengan kehadiran siswa-siswa SMP X di lingkungannya. Program $C B L$ yang dilaksanakan di SMP $\mathrm{X}$ telah menjadi sarana yang bermanfaat bagi para siswa dalam rangka mengaplikasikan pendidikan karakter maupun peningkatan pengetahuan siswa. Hal ini dan sejalan dengan prinsip-prinsip pendidikan karakter yang dijelaskan oleh Lickona, Schaps, dan Lewis (2007), antara lain dengan: mempromosikan nilai-nilai etika sebagai dasar dari karakter yang baik; mendefinisikan "karakter" secara komprehensif, termasuk thinking, feeling, dan behavior; menggunakan pendekatan yang komprehensif, disengaja dan proaktif dalam mengembangkan karakter; menciptakan komunitas yang saling peduli; menyediakan kesempatan bagi siswa untuk melakukan aksi moral; menawarkan kurikulum yang menantang dan bermakna yang menghargai seluruh siswa, mengembangkan karakter, dan membantu mereka untuk meraih kesuksesan; membantu mengembangkan motivasi diri para siswa; melibatkan keluarga dan anggota masyarakat sebagai partner dalam usaha pembentukan karakter; dan sejauh mana para siswa memanifestasikan karakter yang baik.

\section{KESIMPULAN}

Program $C B L$ memiliki dampak terhadap perilaku kerjasama siswa SMP X Depok. Hal ini dapat dilihat dari keseluruhan hasil evaluasi program yang dijabarkan menurut 3 komponen evaluasi, yaitu: evaluasi program menurut komponen evaluasi faktor person (kognitif); evaluasi program menurut komponen evaluasi faktor behavior (perilaku); dan evaluasi program menurut komponen evaluasi faktor environment (lingkungan). Secara kognitif, program $C B L$ yang dilaksanakan di SMP X dapat meningkatkan pemahaman dan pengetahuan para siswa terkait makna dari kerjasama serta cara untuk menjadi anggota tim yang sukses. Adapun para guru menilai bahwa siswa memperoleh manfaat tentang wirausaha, K4, pertanian, menghadapi masalah dalam kelompok, menghadapi anak TK, dan cara menyampaikan pendapat.

Ditinjau dari faktor behaviour (perilaku), para siswa menilai bahwa program $C B L$ di SMP X dapat meningkatkan keterlibatan mereka dalam kerjasama. Hingga saat ini mereka sudah konsisten menjadi bagian dari tim yang sukes. Menurut para guru, saat ini para siswa menunjukkan peningkatan dalam hal perilaku kerjasama. Adapun perilaku kerjasama yang meningkat pada diri siswa tersebut adalah dalam hal semangat, kekompakan, saling menghargai, dan usaha untuk total saat mengerjakan tugas kelompok, dibandingkan sebelum siswa tersebut melaksanakan program $C B L$. Sementara aspek lain, yaitu pelaksanaan peran dalam kelompok, sudah ada ada namun tidak meningkat karena ketidakkonsistenan dari perilaku kerjasamanya.

Berdasarkan faktor environment (lingkungan), program $C B L$ yang dilaksanakan di SMP X ini dapat terlaksana berkat peran dan kerjasama antara pihak-pihak yang terlibat. Pihak pelaksana utama adalah siswa yang terlibat sejak tahap persiapan, pelaksanaan sampai evaluasi (pembuatan laporan dan penutupan dalam bentuk syukuran). Pihak lainnya yang berperan adalah guru di 
SMP X sebagai panitia dan pembimbing sejak tahap persiapan, pelaksanaan sampai dengan evaluasi.

Program ini juga tak lepas dari peran orang tua siswa dan guru-guru TK/SBB di wilayah Depok sebagai mitra dari Sekolah X yang memberikan kontribusi pada tahap persiapan. Begitu pula dengan UPTD, kepolisian, kepala desa, ketua RW dan RT di lokasi pelaksanaan $C B L$, yang berperan memberikan perizinan. Masyarakat di lokasi $C B L$ tentu juga memberikan kontribusi dalam terlaksananya program ini. Masyarakat yang dimaksud antara lain guru-guru TK/SBB di lokasi $C B L$, pemilik rumah tinggal siswa, pemilik UMKM, dan guru-guru SD. Siswa maupun guru menilai bahwa kehadiran siswa SMP X memberikan manfaat yang positif di lingkungan mereka. Bahkan sebagian dari siswa masih memiliki koneksi dengan masyarakat di lokasi $C B L$, misalnya dengan melakukan komunikasi melalui telpon.

Saran yang disampaikan oleh peneliti berkaitan dengan saran teoritis dan saran praktis. Saran teoritis berkaitan dengan bentuk evaluasi program $C B L$ yang dapat dilakukan untuk penelitian selanjutnya. Penelitian selanjutnya dapat menambahkan aspek efektivitas program untuk mengetahui sejauh mana perbedaan karakter siswa sebelum dan sesudah mereka melaksanakan program. Penelitian selanjutnya juga dapat menggunakan partisipan dari sampel siswa yang memiliki skor kerjasama rendah, sedang, dan tinggi. Selain itu, dalam penelitian selanjutnya juga dapat ditambahkan unsur lain dari program $C B L$, misalnya kerjasama antara siswa dengan guru. Adapun saran praktis berkaitan dengan saran untuk peningkatan program di SMP X selanjutnya, meliputi kegiatan pra- $C B L$, kegiatan pasca $C B L$, dan saran untuk orang tua.

Saran praktis yang pertama berkaitan dengan kegiatan pra- $C B L$. Selain berupa kegiatan pencarian dana saat siswa duduk di kelas 7, kegiatan pra- $C B L$ juga dapat diisi dengan pembekalan secara lebih mendalam tentang makna dan praktek kerjasama kelompok yang baik, termasuk bagaimana cara terbaik pada saat menjalankan peran sebagai pemimpin maupun penanggung jawab bidang tertentu. Pembekalan mengenai kerja kelompok tersebut dapat dilakukan di jam pilar karakter. Kegiatan pilar karakter lainnya yang dapat dilakukan sebagai kegiatan pra- $C B L$ adalah latihan mengajar atau latihan kampanye yang diintegrasikan di kegiatan pilar karakter. Sehingga saat siswa sudah duduk di kelas 8 , mereka sudah lebih siap menjadi tim yang sukses dan solid serta siap secara mental untuk melaksanakan $C B L$.

Saran praktis berikutnya berkaitan dengan kegiatan pasca- $C B L$. Konsistensi karakter dalam diri siswa setelah mereka melaksanakan program $C B L$ juga menjadi salah satu hal yang penting. Maka peneliti memberikan saran berupa adanya proyek pasca $C B L$ di sekolah. Peserta program $C B L$ tersebut dapat dilibatkan dalam persiapan program $C B L$ bagi adik kelasnya. Siswa kelas 8 menjalankan program di semester pertama, maka di semester kedua mereka dapat dilibatkan sebagai pembimbing kegiatan pra- $C B L$ bagi adik kelasnya yang duduk di kelas 7 . Peneliti juga memberikan saran kepada orang tua untuk senantiasa mendukung karakter kerjasama ini di lingkungan rumah. Cara yang dapat dilakukan oleh orang tua adalah dengan membentuk perilaku kerjasama melalui pemberian contoh kerjasama yang baik antara ayah dan ibu; mengajak anak-anak untuk berpartisipasi melakukan pekerjaan di rumah secara gotong royong; dan memotivasi anaknya yang berusia remaja untuk terlibat dalam organisasi yang ada di lingkungan rumah. Selain itu, orang tua dapat memberikan apresiasi positif saat anak mau bekerjasama di rumah. Dengan demikian, anak-anak akan semakin termotivasi dan terbiasa melakukan kerjasama sehingga dapat menjadi habbit di rumah, di sekolah, maupun di lingkungan masyarakat. 


\section{Ucapan Terima Kasih (Acknowledgement)}

Ucapan terima kasih penulis sampaikan kepada pihak-pihak yang mendukung penelitian ini, yaitu:

1.Ibu Ratna Megawangi, Ph.D dan Bapak Sofyan A Djalil, Ph.D sebagai Dewan Pembina Indonesia Heritage Foundation (IHF).

2.Ibu Drg. Rahma Dewi, M.Kes selaku Direktur Eksekutif IHF. Juga kepada jajaran direksi internal, eksternal, dan litbang IHF, yaitu Ibu Wahyu Farrah Dina, M.Sc, Ibu Rahma Dona, M.Sc, dan Ibu Florence Yulisinta, M.Sc.

3.Ibu Dian Anggraeni Tri Astuti, M.Si selaku Direktur Sekolah X, Ibu Muhtiarti Rahmi Dewi S.Si selaku Kepala Sekolah SMP X, seluruh staf IHF dan guru di Sekolah X dari jenjang TK, SD dan SMP. Juga kepada murid-murid kelas 9 SMP X tahun ajaran 2016-2017.

\section{REFERENSI}

Bandura, A. (1977). Social learning theory. New Jersey: Prentice-Hall, Inc.

Bandura, A. (1989). Social cognitive theory. In R. Vasta (Ed.), Annals of Child Development, 6, 1 - 60. Greenwich, CT: JAI Press.

Brennan, M.A., \& Barnett, R.V. (2009). Bridging community and youth development: Exploring theory, research, and application. Community Development, 40(4), 305 - 310. doi: $10.1080 / 15575330903279515$

Celio, C.I., Durlak, J., \& Dymnicki, A. (2011). A meta-analysis of the impact of service-learning on students. Journal of Experiential Education, 34(2), $264-181$.

Constructing Excellence. (2004). Effective teamwork. A best practice guide for the construction industry.

Melaville, A., Berg, A.C., \& Blank M.J. (2006). Community based-learning, engaging students for success and citizenship. Coalition for Community School, USA: Washington, DC.

National Oceanic and Athmosphere Administration. (2009). Designing education projects. A comprehensive approach to needs assessment, project planning and implementation, and evaluation ( $2^{\text {nd }}$ eds.). US Departement of Commerce. Diambil dari www.oesd.noaa.gov/leadership/DEP_Manual_2ndEdt_Final.pdf.

Newman, W.L. (2014). Social research methods: Qualitative and quantitative approach (7th ed.). United State of America: Pearson Education Limited.

Nova Scotia Department of Education and Early Childhood Development (2013). Communitybased learning: A resources for school.

Owens, T.R., \& Wang, C. (1996). Community-based learning: A foundation for meaningful educational reform. School Improve Research Series.

Owston, R. (2008). Models and methods for evaluation. Handbook of Research on Educational Communications. York University, Toronto, Canada, p. $605-617$.

Roehlkepartain, E.C. (2007). Benefits of community-based service learning. Scots Valley, CA: Learn and Serve America's National Service-Learning Clearinghouse. Diambil dari www.search-institute.org/downloadable/2007-Roehlkepartain-CBO-Benefits-SLNSLC.pdf.

Rullière, J.L., Santos-Pinto, L., \& Vialle, I. (2011). Self-confidence and teamwork: An experimental test. Working paper GATE 2011-26. Diambil dari http://halshs.archivesouvertes.fr/halshs-00632091.

Tarricone, P., \& Luca, J. (2002). Successful teamwork: A case study. Higher Education Research and Development Society of Australiasia (HERDSA), 640 - 346. 